\title{
Serum ceruloplasmin and paraoxonase-1 levels in ovariectomized and ovariohysterectomized dogs"
}

\author{
Ayhan BAŞTAN ${ }^{1}$, Halit KANCA ${ }^{1}$, İdil BAŞTAN ${ }^{2}$, Seçkin SALAR ${ }^{1}$, Kübra KARAKAŞş $^{1}$, \\ Hasan ALKAN ${ }^{1}$, Tevhide SEL ${ }^{3}$
}

Ankara Üniversitesi, Veteriner Fakültesi, ${ }^{1}$ Doğum ve Jinekoloji Anabilim Dalı; ${ }^{2}$ İç Hastalıkları Anabilim Dalı; ${ }^{3}$ Biyokimya Anabilim Dal1, Ankara.

\begin{abstract}
Summary: The objectives of this study were to evaluate the severity of acute phase reaction and to investigate the paraoxanase-1 (PON-1) activity associated with ovariectomy (OVE) and ovariohysterectomy (OVH) in dogs. A total of 21 adult healthy dogs were included. The dogs were randomly divided into two groups and either ovariectomized ( $\mathrm{n}=10$ ) or ovariohysterectomized $(n=11)$. Peripheral blood samples were collected preoperatively and on postoperative fourth day for serum ceruloplasmin (cp) and paraoxanase-1 activity measurements. Results were compared within and between groups. Potential correlation between paraoxanase- 1 and ceruloplasmin was assessed. Preoperative mean serum ceruloplasmin levels in OVE and OVH groups were $0.80 \pm 0.17$ and $1.65 \pm 0.35 \mathrm{U} / \mathrm{ml}$, respectively $(\mathrm{P}>0.05)$. On postoperative 4 th day, serum ceruloplasmin levels in OVH group $(1.95 \pm 0.47 \mathrm{U} / \mathrm{ml})$ was higher compared to OVE group $(0.69 \pm 0.10 \mathrm{U} / \mathrm{ml} ; \mathrm{P}<0.05)$. Pre- and postoperative serum ceruloplasmin levels were not different within study groups $(\mathrm{P}>0.05)$. Preoperative serum paraoxanase-1 activity in OVE and $\mathrm{OVH}$ groups were $1001.56 \pm 44.60 \mathrm{U} / \mathrm{ml}$ and $1119.10 \pm 87.99 \mathrm{U} / \mathrm{ml}$, respectively $(\mathrm{P}>0.05)$. Higher postoperative serum paraoxanase-1 activity was observed in OVH group $(1065.15 \pm 46.00 \mathrm{U} / \mathrm{ml})$ compared to OVE group $(941.22 \pm 32.57 \mathrm{U} / \mathrm{ml} ; \mathrm{P}<0.05)$. Pre and postoperative serum paraoxanase- 1 activity was not different within study groups $(\mathrm{P}>0.05)$. Paraoxanase-1 activity was not correlated with concentration of ceruloplasmin $(\mathrm{P}=.250 ; \mathrm{r}=0.06)$. In conclusion, OVE is superior to OVH in terms of reducing the severity of postoperative acute phase response. In addition, OVE and OVH does not alter canine paraoxanase-1 activity on postoperative fourth day and paraoxanase-1 activity is not associated with serum concentration of ceruloplasmin in dogs.
\end{abstract}

Keywords: Bitch, Ceruloplasmin, Ovariectomy, Ovariohysterectomy, Paraoxonase-I.

\section{Ovariektomi ve ovaryohisterektomi yapılan köpeklerde serum seruloplazmin ve paraoksonaz-1 düzeyleri}

Özet: $\mathrm{Bu}$ çalışmanın amaçları köpeklerde ovariektomi (OVE) ve ovaryohisterektomi (OVH) ile ilişkili akut faz yanıtının şiddetinin değerlendirilmesi ve paraoksanaz-1 (PON-1) aktivitesinin araştırılmasıydı. Çalışmada toplam 21 adet sağlılı dişi köpek kullanıldı. Köpekler rastgele OVH $(n=11)$ ve OVE $(n=10)$ yapılmak üzere iki gruba ayrıldı. Operasyon öncesinde ve operasyon sonrası 4. günde alınan periferal kan örneklerinde serum seruloplazmin düzeyi ve paraoksonaz-1 aktivitesi ölçüldü. Sonuçlar gruplar içerisinde ve gruplar arasında karşılaştırıldı. Paraoksanaz-1 ve seruloplazmin arasında muhtemel korelasyon değerlendirildi. Operasyon öncesi serum seruloplazmin seviyeleri OVE ve OVH gruplarında sırasıyla $0.80 \pm 0.17$ and $1.65 \pm 0.35$ U/ml olarak ölçüldü $(\mathrm{P}>0.05)$. Operasyon sonras1 4. günde serum seruloplazmin seviyesi $\mathrm{OVH}$ grubunda $(1.95 \pm 0.47 \mathrm{U} / \mathrm{ml}) \mathrm{OVE}$ grubuna kıyasla daha yüksek bulundu $(0.69 \pm 0.10 \mathrm{U} / \mathrm{ml} ; \mathrm{P}<0.05)$. Operasyon öncesi ve sonrası serum seruloplazmin seviyesi çalışma grupları içerisinde farklılık göstermedi $(\mathrm{P}>0.05)$. Operasyon öncesi ve sonrasında serum PON-1 aktivitesi OVE ve OVH gruplarında sırasıyla $1001.56 \pm 44.60 \mathrm{U} / \mathrm{ml}$ ve $1119.10 \pm 87.99 \mathrm{U} / \mathrm{ml}$ olup $(\mathrm{P}>0.05)$, operasyon sonras1 serum PON-1 aktivitesi OVH grubunda $(1065.15 \pm 46.00 \mathrm{U} / \mathrm{ml})$ OVE grubuna kıyasla daha yüksekti $(941.22 \pm 32.57 \mathrm{U} / \mathrm{ml} ; \mathrm{P}<0.05)$. PON-1 aktivitesi ile serum seruloplazmin konsantrasyonu arasında bir korelasyon yoktu $(\mathrm{P}=.250 ; \mathrm{r}=0.06)$. Sonuç olarak, OVE grubunda postoperatif akut faz yanıtının şiddeti OVH grubuna göre daha düşüktü. Buna ek olarak, köpeklerde OVE ve OVH operasyonu sonrası 4. günde PON-1 aktivitesinde değişiklik ve PON-1 aktivitesi ile serum seruloplazmin konsantrasyonları arasında bir ilişki bulunmadı.

Anahtar sözcükler: Dişi köpek, Seruloplazmin, Ovariektomi, Ovaryohisterektomi, Paraoksonaz-I.

\footnotetext{
* This study was presented as a oral communication in V. Congress of Veterinary Obstetrics and Gynaecology (with International Attendee), 31 October-3 November 2013, Antalya, Turkey.
} 


\section{Introduction}

Traditional ovariohysterectomy (OVH) has been the procedure of choice by veterinarians for sterilizing female dogs and reducing the risk of developing mammary cancer and pyometra as the dog ages. This procedure, which is the most common surgery performed in veterinary practice, involves the complete removal of both ovaries and the uterus through a median celiotomy incision. In many European Countries, bilateral ovariectomy was adopted as a viable alternative for neutering female dogs as early as 1981 when Utrecht University began performing this surgery preferentially over the traditional OVH. Since this time, there have been no documented increases in either short-term surgical complications or long-term effects such as pyometra associated with not performing a full ovariohysterectomy. However, evidence that would identify whether either technique could be considered superior for routine neutering of dogs is needed because there are no randomized studies comparing the two procedures (6).

Any surgical intervention causes an acute phase response which refers to a nonspecific and complex reaction of an animal that occurs shortly after tissue injury. The aim of acute phase reaction is to restore homeostasis and to remove the cause of its disturbance. The response includes changes in the concentration of plasma proteins, and called acute phase proteins (APPs) (1). Ceruloplasmin is one of the major positive APPs in dogs. It plays an important role in protecting host tissues from toxic oxygen metabolites. Level of serum ceruloplasmin is a good indicator to evaluate inflammation status and surgical trauma (2).

Paraoxonase-1 (PON1) is an enzyme associated with high-density lipoproteins (HDL) that protects low density lipoproteins and HDL from peroxidation. Paraoxonase-1 is mainly expressed in the liver and is transported in plasma bound to HDL. During an acute phase response, HDL molecules lose apolipoprotein A1, esterified cholesterol, and most of the HDL-associated enzymes, including PON-1, which is replaced mainly by serum amyloid $\mathrm{A}$ and ceruloplasmin. Altogether, this results in reduced antioxidative properties of HDL. In both laboratory animals and people, changes in HDL composition and structure during an acute phase response inactivate the already synthesized PON-1 and, in addition, the hepatic gene expression of PON-1 is inhibited. For these reasons, PON-1 is considered a negative acute phase protein (APP). Except for laboratory animals, there are few reports about PON-1 as a negative inflammatory marker in veterinary medicine. Despite the possible clinical usefulness of PON-1 as an inflammatory marker, especially in inflammatory conditions associated with oxidative damage, only a few studies are available about PON-1 activity in dogs (11).
The objectives of this study were to investigate the severity of acute phase reaction and to investigate the PON-1 activity associated with ovariectomy and ovariohysterectomy in dogs.

\section{Materials and methods}

Materials: Twenty-one adult healthy dogs were used. Dogs were weighing 16.1-20.3 kg and they were 24 years of age. Physical examination of the bitches was performed. As subclinical infections might change serum ceruloplasmin and paraoxonase activity, blood samples were taken for complete blood count and animals having physiological complete blood count parameters were included. The dogs were randomly divided into two groups balanced for age and weight and they were either ovariectomized $(\mathrm{n}=10)$ or ovariohysterectomized $(\mathrm{n}=11)$. The study was approved by the Local Ethics Committee on Animal Experiments of Ankara University, Ankara, Turkey (Approval No: 2013-4-27).

Surgical Procedure: Water and food were withheld for 8 and 12h, respectively prior to surgery. Premedication was achieved with atropine sulphate at $0.044 \mathrm{mg} / \mathrm{kg}$ SC. A venous catheter was placed in the cephalic vein for the induction of anaesthesia and continuous infusion of isotonic saline solution during the surgery. Anaesthesia was induced with propofol $6 \mathrm{mg} / \mathrm{kg}$ IV (Propofol 1\% ${ }^{\circledR}$ Fresenius Kabi). The dogs were intubated and anaesthesia was maintained with isoflurane (Forane ${ }^{\circledR}$ Abbott Laboratories Ltd) in oxygen at a flow rate of $2 \%$. During anaesthesia ECG, heart rate, respiratory rate, $\mathrm{SpO} 2$ (Oxygen Saturation) and body temperature were monitored.

The dogs were restrained in dorsal recumbency and the surgical field was prepared in the standard manner for all abdominal operations. Both techniques were performed through median celiotomy. Skin incision for ovariectomy was extended from umbilicus to approximately halfway between umbilicus and os pubis, depending on dog size. The ovary was located, and retracted caudally to expose the suspensory ligament and ovarian pedicle. The suspensory ligament was stretched, broken by scissor, to improve manipulation and observation of the pedicle. The arteriovenous complex within the pedicle, arising from the ovarian artery and vein was ligated with $0-1$ size absorbable suture material, depending on pedicle size, after which it was transected. The uterine artery and vein were ligated at the cranial tip of the uterine horn, $5 \mathrm{~mm}$ caudal to the proper ligament, using 2/0-1/0 absorbable suture material, and transected at the proper ligament.

Ovariohysterectomy was performed through a median celiotomy, depending on the dog's size; the incision was lengthened in a caudal direction. After the ovarian pedicles were ligated and cut. A ligature was placed on the uterine body just cranial to, or, the cervix. 
The uterine arteries were individually ligated proximal to the clamp using 2/0-3/0 absorbable suture material and the uterus, was ligated circumferentially in the crushing groove that remains after removal of the clamp using 03/0 absorbable suture material. After inspection for potential bleeding at the ligated pedicles, the celiotomy was closed in layers.

All dogs were treated with bandages after surgery. The bandage was changed at intervals of 2 days until skin sutures were removed. All dogs were monitored postsurgically for local and systemic infection and for wound healing. The dogs received amoxicillin-clavulanic acid (Synulox ${ }^{\circledR}$, Pfizer), $12.5 \mathrm{mg} / \mathrm{kg}$, for 5 days. Skin sutures were removed on days 8-10.

Ceruloplasmin and Paraoxanase-1 Measurements: Peripheral blood samples were collected preoperatively and on postoperative fourth day for serum cp and PON-1 measurements. The samples were centrifuged at 3000 $\mathrm{rpm}$ for 10 minutes and sera were frozen at $-80^{\circ} \mathrm{C}$. A method based on that described by Sunderman and Nomoto (13), with the modifications of Ceron and Subiela (2) was used for determination of ceruloplasmin values. At $\mathrm{pH} 5.2$, cp catalyses the oxidation of $\mathrm{p}$ phenylenediamine dihydrochloride to yield a colored product. The rate of formation of the colored oxidation product is proportional to the concentration of serum $\mathrm{cp}$. Paraoxonase activitity in serum was measured as the rate of hydrolysis of paraoxon at $412 \mathrm{~nm}$ and $37^{\circ} \mathrm{C}$ in 0.05 $\mathrm{mmol} / \mathrm{L}$ glycine buffer ( $\mathrm{pH} 10.5$ ) with $1 \mathrm{mmol} / \mathrm{L} \mathrm{CaCl}_{2}$.

Statistical Analyses: Data are presented as means \pm standard errors $(\mathrm{X} \pm \mathrm{SE})$. Statistical analyses were performed using the SPSS software ${ }^{\circledR}$ (Version 17 for Windows; SPSS Inc., Chicago, IL, USA). Data obtained were checked for normal distribution using the Kolmogorov-Smirnov test. Comparisons of two mean values within one group were performed using the Paired Sample T-Test and comparisons between groups with the Independent Samples T-Test. A P value of $<0.05$ was considered statistically significant. Potential correlation between PON-1 and cp was assessed using the Pearson Correlation test.

\section{Results}

Preoperative mean serum ceruloplasmin levels in OVH and OVE groups were $1.65 \pm 0.35$ and $0.80 \pm 0.17$ $\mathrm{U} / \mathrm{ml}$, respectively $(\mathrm{P}>0.05)$. On postoperative 4 th day, serum ceruloplasmin levels in OVH group $1.95 \pm 0.47$ was higher compared to OVE group $(0.69 \pm 0.10 \mathrm{U} / \mathrm{ml}$; P $<0.05)$. Pre- and postoperative serum ceruloplasmin levels were not different within study groups $(\mathrm{P}>0.05$; Table 1).

Preoperative serum paraoxonase-1 levels in $\mathrm{OVH}$ and OVE groups were 1119.10 \pm 87.99 and $1001.56 \pm 44.60 \mathrm{U} / \mathrm{ml}$, respectively $(\mathrm{P}>0.05)$. Higher postoperative serum paraoxonase-1 levels were observed in OVH group (1065.15 \pm 46.00$)$ compared to OVE group $(941.22 \pm 32.57 ; \mathrm{P}<0.05)$. Pre and postoperative serum paraoxonase-1 levels were not different within study groups ( $\mathrm{P}>0.05$; Table 2). According to Pearson correlation, PON-1 activity was not correlated with concentration of ceruloplasmin $(\mathrm{P}=.250 ; \mathrm{r}=0.06$; Figure 1$)$.

Table 1. Serum ceruloplasmin levels pre and 4th days postoperative in ovariectomized and ovariohysterectomized dogs (U/ml).

Tablo 1. Ovariektomi ve ovaryohisterektomi yapılan köpeklerde operasyon öncesi ve operasyon sonrası 4. günde serum seruloplazmin düzeyleri.

\begin{tabular}{lccc}
\hline & $\begin{array}{c}\text { Pre-operative } \\
(\text { Mean } \pm \text { SE) } \\
(\text { min-max })\end{array}$ & $\begin{array}{c}\text { Post-operative } \\
(\text { Mean } \pm \text { SE) } \\
(\text { min-max })\end{array}$ & $\begin{array}{c}\mathrm{P} \\
\text { value }\end{array}$ \\
\hline OVH & $1.65 \pm 0.35$ & $1.95 \pm 0.47$ & $>0.05$ \\
$(\mathrm{n}=11)$ & $(0.38-4.03)$ & $(0.19-4.60)$ & \\
\hline OVE & $0.80 \pm 0.17$ & $0.69 \pm 0.10$ & $>0.05$ \\
$(\mathrm{n}=10)$ & $(0.58-2.30)$ & $(0.19-1.15)$ & \\
\hline P value & $>0.05$ & $<0.05$ & \\
\hline
\end{tabular}

Table 2. Serum paraoxonase-1 levels pre and 4th days postoperative ovariectomized and ovariohysterectomized dogs (U/ml). Tablo 2. Ovariektomi ve ovaryohisterektomi yapılan köpeklerde operasyon öncesi ve operasyon sonrası 4. günde serum paroksonaz-1 düzeyleri.

\begin{tabular}{lccc}
\hline & $\begin{array}{c}\text { Pre-operative } \\
(\text { Mean } \pm \text { SE) } \\
(\min -m a x)\end{array}$ & $\begin{array}{c}\text { Post-operative } \\
(\text { Mean } \pm \text { SE) } \\
(\text { min-max })\end{array}$ & $\begin{array}{c}\mathrm{P} \\
\text { value }\end{array}$ \\
\hline $\mathrm{OVH}$ & $1119.10 \pm 87.99$ & $1065.15 \pm 46.00$ & $>0.05$ \\
$(\mathrm{n}=11)$ & $(779.80-1815.80)$ & $(900.20-1436.40)$ & \\
\hline $\mathrm{OVE}$ & $1001.56 \pm 44.60$ & $941.22 \pm 32.57$ & $>0.05$ \\
$(\mathrm{n}=10)$ & $(835.80-1253.0)$ & $(760.20-1083.60)$ & \\
\hline $\mathrm{P}$ value & $>0.05$ & $<0.05$ & \\
\hline
\end{tabular}

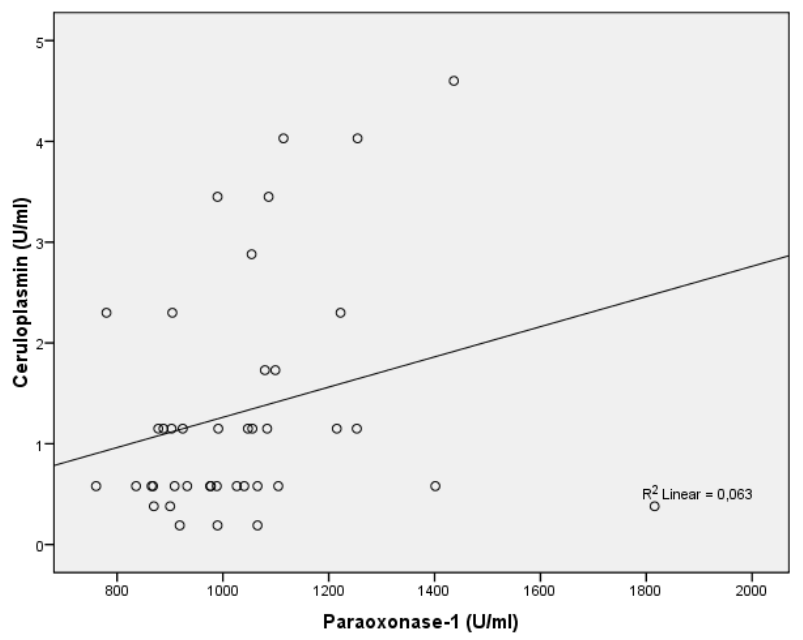

Figure 1. Pearson correlation between paraoxanase-1 activity and concentration of ceruloplasmin in serum samples.

Şekil 1. Serum örneklerinde paraoksanaz-1 aktivitesi ile seruloplazmin konsantrasyonu arasındaki Pearson korelasyonu. 


\section{Discussion and Conclusion}

Ceruloplasmin is one of the important positive acute phase proteins in dogs. Serum cp levels increase after surgical trauma and it is accepted that $\mathrm{cp}$ is good indicator for severity of surgical intervention (2). Two to three fold increases, with peak concentrations on the fourth day following surgery were reported (3). However, serum cp levels did not change after OVH and OVE in the current study. The lack of increase in serum cp levels could be explained by severity of the surgical trauma as the level of trauma is relatively low for both surgical procedures used in the present study. In accordance with our results, no change in serum $\mathrm{cp}$ following OVH was observed in two recent studies (9, 12). In addition, cp synthesis has been reported to be enhanced by iron deficiency and by circulating estrogen and progesterone levels (5). Collectively, it is suggested that serum cp measurement might not be an appropriate parameter in evaluating acute phase response following $\mathrm{OVH}$ and $\mathrm{OHE}$ in dogs.

Elective neutering in female dogs and cats can be accomplished by removing both ovaries and uterus $(\mathrm{OVH})$ or by removing the ovaries alone (OVE). Ovariohysterectomy and ovariectomy involve similar surgical techniques, except that the skin and fascia incisions are considerably smaller and located more cranially with OVE, compared with OVH (4). The results of the current study show that OVH causes more severe acute phase response compared to OVE. This is not surprising because from a technical perspective, OVE is less invasive than OHV. Although it is possible to do OVH through a small median celiotomy, atraumatic procedure and correct placement of the uterine ligature near cervix typically requires a larger celiotomy compared with OVE. Thus, the duration of surgery and anesthesia should be shorter, the broad ligaments are not disrupted, and the uterine stumph left intact, there should also be less surgical trauma (8). For both better clinical outcome and animal welfare the surgeon has to choose the least invasive, fastest, and safest procedure. The current study favors OVE over OVH in for elective neutering of dogs.

An objective of the current study was to assess the possible role of PON-1 as a negative APP in dogs after surgical trauma and to compare PON-1 activity with the concentration of $\mathrm{cp}$ a major canine positive APP. Oxidative stress in the body represents an imbalance between the production of reactive oxygen species and the ability of the antioxidant defense mechanisms to detoxify the reactive intermediates. The greater the oxidative stress, the more severe the resulting cellular damage during surgery may cause poor outcome in patients (10). It has been established that $\mathrm{OVH}(7,12)$ and OVE (10) causes oxidative stress in dogs. In the current study serum PON-1 activity on postoperative fourth day were not different from preoperative levels in both study groups. Unexpectedly, higher PON-1 activity was observed after OVH compared to OVE. To our knowledge, there is no previous report on the PON-1 activity in dogs after any surgical intervention. Low surgical intensity of OVH and OVE might be responsible for hindering alterations in PON-1 activity after surgery, as it is the case for serum cp concentrations. Furthermore, postoperative fourth day, which was chosen in the current study to match up with possible cp peak, should not be a suitable time point for detecting PON-1 activity alterations after surgical procedures. It has also been reported that PON-1 activity in dogs could be affected by many preanalytical factors such as moderate to severe hemolysis, severe lipemia and different storage conditions (11).

There was no clear association between PON-1 activity and serum concentration of cp. Similarly, Rossi et al., (11) reported that that PON-1 activity is not related to $C$ reactive protein and $\alpha-2$-globulin, two major canine APPs. These results suggest that PON-1 activity does not seem to provide a diagnostic help for acute phase response in dogs after elective neutering. Collectively, OVH and OVE do not alter PON-1 activity on postoperative fourth day in dogs, and PON-1 activity after surgical trauma in dogs remains to be elucidated.

In conclusion, OVE is superior to $\mathrm{OVH}$ in terms of reducing the severity of postoperative acute phase response. In addition, OVE and $\mathrm{OVH}$ does not alter canine PON-1 activity on postoperative fourth day and PON-1 activity is not associated with serum concentration of ceruloplasmin in dogs.

\section{References}

1. Ceron JJ, Eckersall PD, Subiela SM (2005): Acute phase proteins in dogs and cats: current knowledge and future perspectives. Vet Clin Pathol, 34, 85-99.

2. Ceron JJ, Subiela SM (2004): An automated spectrophotometric method for measuring canine ceruloplasmin in serum. Vet Res, 35, 671-679.

3. Conner JG, Eckersall PD, Ferguson J, Douglas TA (1988): Acute phase response in the dog following surgical trauma. Res Vet Sci, 45, 107-110.

4. De Tora M, McCarty RJ (2011): Ovariohysterectomy versus ovariectomy for elective sterilization of female dogs and cats: is removal of the uterus necessarry?. JAVMA, 239, 1409-1412.

5. Eckersall PD (2008): Proteins, Proteomics and Dysproteinemias. 117-155. In: JJ Kaneko, JW Harvey, ML Bruss, Clinical Biochemistry of Domestic Animals. 6th Ed, Academic Press, San Diego.

6. Goethem BV, Schaefers-Okkens A, Kirpensteijn J (2006): Making a rational choice between ovariectomy and ovariohysterectomy in the dog: a discussion of the benefits of either technique. Veterinary Surgery, 35, 136143. 
7. Gunay A, Gunes N, Gunay U (2011): Effect of ovariohysterectomy on lipid peroxidation and levels of some antioxidants and biochemical parameters in bitches. Bull Vet Inst Pulawy, 55, 695-698.

8. Kirpensteijn J (2008): Ovariectomy versus ovariohysterectomy. Is the eternal argument ended. Proceedings of the international SCIVAC Congress, Rimini, Italy, 290-293.

9. Kum C, Voyvoda H, Sekkin S, Karademir U, Tarimcilar T (2013): Effects of carprofen and meloxicam on $C$-reactive protein, ceruloplasmin, and fibrinogen concentrations in dogs undergoing ovariohysterectomy. Am J Vet Res, 74, 1267-1273.

10. Lee JY, Kim MC (2014): Comparison of oxidative stress status in dogs undergoing laparoscopic and open ovariectomy. J Vet Med Sci, 76, 273-276.

11. Rossi G, Giordano A, Pezzia F, Kjelgaard-Hansen M, Paltrinieri S (2013): Serum paraoxonase 1 activity in dogs: preanalytical and analytical factors and correlation with $C$-reactive protein and alpha-2-globulin. Vet Clin Pathol, 42, 329-341.
12. Serin G, Kiral F, Serin I (2008): Acute effect of ovariohysterectomy on lipid peroxidation and some antioxidant levels in dogs. Bull Vet Inst Pulawy, 52, 251253.

13. Sunderman FW, Nomoto S (1970): Measurement of human serum ceruloplasmin by its p-phenylenediamine oxidase activity. Clin Chem, 16, 903-910.

Geliş tarihi: 16.04.2014/ Kabul tarihi: 29.08.2014

Address of correspondence:

Prof. Dr. Ayhan Baştan

Ankara University,

Faculty of Veterinary Medicine

Department Obstetrics and Gynecology

06110, Dışkapı, Ankara-Turkey.

e-mail:abastan@ankara.edu.tr 